\title{
100-Year Anniversary of Anthroposophic Medicine as an Integrative Medical System
}

\author{
David Martin ${ }^{\mathrm{a}, \mathrm{b}}$ \\ ${ }^{a}$ Department of Human Medicine, Faculty of Health, University Witten/Herdecke, Herdecke, Germany; \\ bTübingen University Children's Hospital, Tübingen University, Tübingen, Germany
}

As I write this editorial, I am attending what may be the largest congress since the corona pandemic lockdown: over 800 health professionals are meeting for 1 week at the Goetheanum in Switzerland to celebrate "100 Years of Anthroposophic Medicine" - strictly abiding to the Swiss regulations of keeping $1.5 \mathrm{~m}$ distance and/or wearing a mask (correcting the proofs of this article a few weeks later I can say that there were no cases of COVID-19 in any of the participants following this event). Due to the pandemic, many people from around the world are not able to attend this event. Thanks to the pandemic, the celebration has become decentralized, with over 50 countries participating: This year, 2020, is celebrated worldwide as the 100th anniversary of anthroposophic medicine (AM), an integrative medical system [1]. Its founders, Rudolf Steiner, PhD (1861-1924), and Ita Wegman, MD (1876-1943), were determined to establish a holistic medical system that would overcome the reductionism of their time. From the beginning, AM was thought of as an integrative medicine that encompasses mainstream medicine. Steiner was striving to complement outer scientific cognition with inner scientific, intuitive cognition according to his epistemology and, from that basis, to inspire doctors to practice what he called in 1920 "intuitive medicine" [2].

Anthroposophy distinguishes

- the spatial-physical body (Greek: sarx) from other levels of organization that need their own, ever more intuitive and artistic science;

- the life organization - the chronobiologically, rhythmically ordered form of permanent (self)change of the body through nutrition, growth, adaptation, differen- tiation, up to reproduction (Greek: soma; etheric body);

- the organization of sensations, affects, wakefulness, drive, motor skills (Greek: psyche; soul body);

- the spiritual individuality transcending space and time, reflexive consciousness/self-reflection and selfawareness, language, ability to question, judge, and execute values, meaning, impulse control, and conscious action (Greek: pneuma) [3].

Within these 4 dimensions of being, a 3-fold human develops with (1) a nerve-sense system, building the basis for sense perception and thinking, (2) a rhythmic system (respiration and circulation), building the basis for feeling, and (3) a metabolic-limb system, building the basis for willpower.

AM tries to encompass people's spiritual, soul, vital, and physical aspects in a methodologically appropriate manner and to integrate them into a resource-oriented medical understanding of health and illness, diagnostics, and therapy [4-8]. This necessarily goes hand in hand with individualization because the aspects mentioned are different for each patient and interact in different ways, even if the medical diagnosis, e.g., hypertension, is the same. If one takes these differences in diagnosis and therapy into account, this results in different, sometimes even polar, therapy concepts - especially if one does not only want to "adjust" the blood pressure (again), but also wants to empower the patient [9]. This is an artistic, rational, and intuitive process.

AM strives to integrate all 3 pillars of evidence-based medicine [10-12] and to be a patient-centered, individualized scientific holistic medical system. It is practiced in 
over 80 countries and includes the entire range of allopathic (conventional) medicine as well as "anthroposophic medicines," counseling and pastoral care, art and exercise therapies (eurythmy therapy, Bothmer gymnastics, Spacial Dynamics ${ }^{\circledR}$, painting, and music therapy, modelling and speech), various forms of physiotherapy and massage (rhythmic massage according to Dr. Ita Wegman, massage according to Dr. med. Simeon Pressel, and others), oil dispersion bath therapy and external applications [13-21]. A wide range of mineral, vegetable and animal substances from nature are used and further processed according to special pharmaceutical procedures. These procedures are laid down in a separate pharmacopeia, recorded and protected by German law (SGB V) [22].

AM is realized in the outpatient medical system for general practitioners, specialists (pediatricians, internists, cardiologists, gastroenterologists, oncologists, gynecologists, dermatologists, ENT specialists, as well as psychiatry and psychosomatics, etc.) and is partially integrated into the statutory health insurance reimbursement system.

$\mathrm{AM}$ is also developing in the acute inpatient hospital sector, such as in rehabilitation. In Germany and Switzerland, there are anthroposophic hospitals of various care levels, from basic and standard care hospitals to specialty care hospitals and academic teaching hospitals at universities (Charité Berlin, University Witten-Herdecke, University of Bern). All of these additional therapies are integrated into the remuneration system of the health insurance companies for hospitals (DRG and PEEP system) and are fully reimbursed. This means that AM has the highest level of penetration of integrative medicine in Germany and Switzerland, as these additional therapies in particular are fully compensated for in the inpatient sector; in Switzerland this also covers the outpatient sector.

Anthroposophic hospitals (AnthroMed ${ }^{\circledR}$ certified hospitals), hospices, and centers offer a large spectrum of services, such as surgery and conservative therapies, palliative medicine, pain therapy, and rehabilitation, including conventional certification as a top center in oncology (so-called Cancer Center according to OnkoZert ${ }^{\circledR}$ ). Viscum (mistletoe) therapy in cancer treatment is probably the most well-known medicinal modality of AM, investigated in many oncological studies as a possible cancer treatment [21-26]. Complex medical and pain conditions in chronic illnesses and in oncology, as well as especially in psychosomatics and psychiatry, can be treated quite successfully [20].

Concepts from AM have been adopted and adapted by conventional medicine [27]. AM has also had a strong influence on the design of a therapeutic milieu through architecture, color schemes for rooms, etc. The anthropo- sophic impulse extends far beyond medicine. It bridges to therapeutic educational approaches for children with special needs as well as social therapy in community settings for adults with learning disabilities (e.g., in some centers, the international Camphill Movement); pedagogy (e.g., the Waldorf school movement), and a sustainable, ecological (biodynamic, Demeter) agriculture and way of life. In addition, anthroposophic impulses today extend into social and economic life with banks (GLSBank; Triodos-Bank, etc.) and cultural life (drama, eurythmy, painting, music, singing, literature, and philosophy). The AM pharmaceutical industry (Wala, Weleda, Abnoba, Helixor, Iscador) produces over 1,200 medicines for AM according to their own and officially acknowledged pharmacopoeia.

As a developing medical system, AM endeavors to scientifically evaluate its methods and procedures. Already in 1982, the community hospital Herdecke gave the impulse for the first recognized private university in Germany, the Witten/Herdecke University. Today, there are not only a Chair for AM and a professorship for AM Training and Education at Witten/Herdecke University, but also professorships for AM at the Charité (Berlin) and the universities of Bern, Freiburg, Basel, and Leyden. Numerous independent research institutes complement the research landscape for AM. As part of the integration of AM into the Swiss public health system, the AM system was subjected to a Health Technology Assessment, the highest form of evidence assessment, and rated as scientifically adequately secured [28]. An overview of the various research fields and the most important publications can be found at https://medsektion-goetheanum.org/en/ research/. Well over 1,000 scientific publications have already been published to evaluate AM. Training and research in art therapy and eurythmy therapy have been academized since 2003 at the Alanus University for Art and Society. AM, therefore, has achieved a very high degree of academization of integrative medical methods in Germany (https://medsektion-goetheanum.org/forschung/research-institutions/).

Anthroposophic doctors have a double qualification: university education with license to practice and a further medical training for AM comprising at least 1,000 h, with courses, mentored practice, project work, and case studies. The trainings are offered in each country by its own anthroposophic medical association or via an international training program (IPMT = International Postgraduate Medical Training). In addition, there are international English language trainings based in the UK and in the USA, partly online. All trainings are accredited through the Medical Section at the Goetheanum, Switzerland (https://medsektion-goetheanum.org/ausbildung/). In-house nursing training is also available at several centers (www.vfap.de/berufsausbildung-verband). 
Even though a lot has undoubtedly been achieved in 3 generations, AM is still generally regarded as being in the infancy of its full potential. The author has experienced $\mathrm{AM}$ to be very helpful and relevant in his own medical career. Medical studies were enriched as anatomy, physiology, botany, pathology, etc. became fascinating when studied within the holistic context of AM. Further, AM has been a deep inspiration, both in treating and supporting patients as well as being a constant spur to keep up to date in mainstream medicine $[13,14]$ (see also www.anthromedic.org). Further, AM keeps one alert to the fact that medicine is a service to fellow human beings, not a means to a personal end. AM should not be practiced with financial profit in mind. Even though AM can appear very comprehensive, younger students are well-advised to constantly broaden their knowledge and capacities, both through mainstream and various branches of integrative medicine. As in all fields of medicine, there is the risk of practicing and prescribing in AM out of convention or imitation, without adequate rational or acquired experiential basis. However, recent developments, such as the publication of a Vademecum of Anthroposophic Medicines and the Vademecum of External Applications in Anthroposophic Nursing (both accessible via www.vademecum.org), offer practitioners and researchers the possibility of sharing experiences and offering mutual feedback. This builds a certain level of evidence at a time when testing all medicines for all diagnoses through randomized controlled trials would be logistically and financially impossible.

As a sidenote, although AM hospitals are renowned for their excellent organic food, the world is changing fast and they should be careful to cultivate this area so that being a patient in an AM hospital continues to be a living model for meeting the needs of body, soul, and spirit (AM hospitals in Germany and Switzerland are repeatedly at the top of patient rankings). Thus, holistic, people-orient- ed treatment is also reflected in patient perception. AM works to promote self-management $[29,30]$ and personal development [31] and to include patients' perception in research to develop interventions fitting needs [3234]. The Swiss National Science Foundation study on quality of life and anthroposophic treatment of incurable cancer [35] and the ambulatory sector [36] show better performance of anthroposophic practice compared with conventional medicine in overall patient satisfaction, including fulfillment of their expectations of therapy and, for example, significantly lower use of antibiotics. Finally, study, personal development, and disciplined inner schooling, all traditionally hallmarks of AM, need to be cultivated intensively and creatively if AM is to continue to evolve and flourish.

To what extent AM can make a relevant contribution to health and development in the world will depend on the spiritual [37] and professional development of the people working out of it, including so-called patients. "Healing conditions are only achieved when the whole community is reflected in the human soul and when in the community the strength of the single soul is manifest" [38].

Yes, it is a time for thankfulness for what has been achieved in medicine out of anthroposophy, and especially a time for humility and courage in the face of all that is needed in the medical, scientific, socio-political, ecological, economic, and purely human sphere before we can claim really to have achieved an integrative medical system. May AM continue to be one of the many ingredients and catalysts in this direction.

\section{Conflict of Interest Statement}

The author declares no conflicts of interest

\section{References}

1 Steiner R, Wegmann I. Grundlegendes für eine Erweiterung der Heilkunst. 1977 ed. Vol. GA 27. Dornach/Schweiz: Rudolf Steiner Verlag; 1925. p. 40-4.

2 Steiner R. Vom Einheitsstaat zum dreigliedrigen Organismus. GA 334. 1983. p. 53.

3 Steiner R. Von Seelenrätseln. GA 21. 1983.

4 Schad W. Gesundheit und Krankheit in Medizin und Ökologie. Merkurstab. 1998;51(4): 193-7.

5 Antonovsky A. The Structural Sources of Salutogenic Strengths. In: Cooper CL, Payne R, editors. Individual Differences: Personality and Stress. New York: Wiley; 1994. p. 67-104.

6 Starling EH. The Wisdom of the Body: The Harveian Oration, delivered before The Royal College of Physicians of London on St. Luke's Day, 1923. BMJ. 1923 Oct;2(3277):685-90.
7 Weiss PA. Das lebende System: Ein Beispiel für den Schichtendeterminismus. In: Koestler A, Smythies JR, editors. Das neue Menschenbild. Wien, München, Zürich: Molden; 1970.

8 Heusser P. Anthroposophy and Science. An introduction. Frankfurt am Main, Bern, Bruxelles, New York, Oxford: Peter Lang Edition; 2016. https://doi.org/10.3726/978-3653-06753-8.

9 Bopp A, Breitkreuz T. Bluthochdruck senken; das 3-Typen Konzept. GU Ratgeber Gesundheit. Gräfe und Unzer; 2009.

10 Sackett DL. Evidence-based medicine. Semin Perinatol. 1997 Feb;21(1):3-5.

11 Sackett DL, Rosenberg WM, Gray JA, Haynes RB, Richardson WS. Evidence based medicine: what it is and what it isn't. BMJ. 1996 Jan; 312(7023):71-2.
12 Sackett DL, Richardson WS, Rosenberg WH, Haynes B. Evidence-based medicine. How to practice and teach EBM. New York, Edinburgh, London, Madrid: Churchill Livingstone; 1997. p. 1-250.

13 Girke M. Innere Medizin, Grundlagen und therapeutische Konzepte der Anthroposophischen Medizin. 2nd ed. Berlin: SalumedVerlag; 2012.

14 Soldner G, Stellmann M. Individuelle Pädiatrie: Leibliche, seelische und geistige Aspekte in Diagnostik und Beratung, 5. Auflage. Stuttgart: Wissenschaftliche Verlagsgesellschaft; 2018 (English Edition: Individual Paediatrics: Physical, Emotional and Spiritual Aspects of Diagnosis and Counseling - Anthroposophic-Homeopathic Therapy, Fourth Edition. CRC Press; 2018). 
15 Hamre HJ, Glockmann A, Marti J, Soldner G. Mapping Physicians' Experiences with $\mathrm{Me}$ dicinal Products from Whole Medical Systems: A Descriptive Analysis of the Vademecum of Anthroposophic Medicines. Complement Med Res. 2020;27:336-46. https://doi. org/10.1159/000507541.

16 Husemann A, Schad W. Zum Selbstverständnis der Anthroposophischen Medizin. Merkurstab. 2010;63(4):591-2.

17 Glöckler M, Girke M, Matthes H. Anthroposophische Medizin und ihr integratives Paradigma. In: Uhlenhoff R, editor. Anthroposophie in Geschichte und Gegenwart. Berlin: BWV, Berliner Wissenschafts-Verlag; 2011. p. 515-612.

18 Büssing A, Cysarz D, Edelhäuser F, Bornhöft G, Matthiessen PF, Ostermann T. The oil-dispersion bath in anthroposophic medicine an integrative review. BMC Complement $\mathrm{Al}$ tern Med. 2008 Dec;8(1):61.

19 Büssing A, Ostermann T, Majorek M, Matthiessen PF. Eurythmy Therapy in clinica studies: a systematic literature review. BMC Complement Altern Med. 2008 Mar;8(1):8.

20 Kienle GS, Kiene H, Albonico H. Anthroposophic Medicine. Effectiveness, utility, costs, safety. Stuttgart, New York: Schattauer Verlag; 2006.

21 Kienle GS, Albonico HU, Baars E, Hamre HJ, Zimmermann P, Kiene H. Anthroposophic medicine: an integrative medical system originating in Europe. Glob Adv Health Med. 2013 Nov;2(6):20-31

22 Meyer U, Pedersen PA. Anthroposophische Pharmazie, Grundlagen, Herstellprozess, Arzneimittel. Volume 1. Berlin: Salumed Verlag $\mathrm{GmbH} ; 2016$.

23 Kienle GS, Kiene H. Die Mistel in der Onkologie. Stuttgart, New York: Schattauer Verlag; 2003. p. 1-749.
24 Kienle GS, Glockmann A, Schink M, Kiene H. Viscum album L. extracts in breast and gynaecological cancers: a systematic review of clinical and preclinical research. J Exp Clin Cancer Res. 2009 Jun;28(1):79.

25 Loef M, Walach H. Quality of life in cancer patients treated with mistletoe: a systematic review and meta-analysis. BMC Complement Med Ther. 2020 Jul;20(1):227.

26 Ostermann T, Appelbaum S, Poier D, Boehm K, Raak C, Büssing A. A Systematic Review and Meta-Analysis on the Survival of Cancer Patients Treated with a Fermented Viscum album L. Extract (Iscador): An Update of Findings. Complement Med Res. 2020;27(4):26071

27 Jäger RM, Martin D. Kunsttherapie: Alle Künste unter einem Begriff. Deutsches Ärzteblatt. 2020 Aug; 19:354. https://www.aerzteblatt.de/treffer? mode $=$ s\&wo $=32 \&$ typ $=32 \&$ aid $=214937 \& s=$ matti\&s $=$ ralf

28 Kienle GS, Kiene H, Albonico HU. Anthroposophische Medizin: Health Technology Assessment Bericht - Kurzfassung. Forsch Komplement Med. 2006;(13 Suppl 2):7-18.

29 Kröz M, Reif M, Glinz A, Berger B, Nikolaou A, Zerm R, et al.; CRF-2 study group. Impact of a combined multimodal-aerobic and multimodal intervention compared to standard aerobic treatment in breast cancer survivors with chronic cancer-related fatigue - results of a three-armed pragmatic trial in a comprehensive cohort design. BMC Cancer. 2017 Mar;17(1):166

30 Baars EW, Koster EB, Verhoef J. The Contribution of Anthroposophic Medicine to SelfManagement: An Exploration of Concepts, Evidence, and Patient Perspectives. Complement Med Res. 2017;24(4):225-31.
31 Michaelis R, Niedermann C, Reuber M, Kuthe M, Berger B. "Seizures have become a means of somehow learning things about myself" - A qualitative study of the development of self-efficacy and mastery during a psychotherapeutic intervention for people with epilepsy. Epilepsy Behav. 2018 Jul;84:152-61.

32 Koster EB, Baars EW, Delnoij DM. Patientreported quality of care in anthroposophic and integrative medicine: A scoping review. Patient Educ Couns. 2020 Feb;103(2):276-85.

33 Berger B, Bertram M, Kanitz J, Pretzer K, Seifert G. "Like walking into an empty room": effects of eurythmy therapy on stress perception in comparison with a sports intervention from the subjects' perspective - a qualitative study. Evid Based Complement Alternat Med. 2015;2015:856107.

34 Koster EB, Baars EW, Delnoij DM. Patientcentered outcomes on quality of life and anthroposophic healthcare: a qualitative triangulation study. Qual Life Res. 2016 Sep;25(9): 2257-67.

35 Heusser P, Braun SB, Bertschy M, Burkhard R, Ziegler R, Helwig S, et al. Palliative in-patient cancer treatment in an anthroposophic hospital: II. Quality of life during and after stationary treatment, and subjective treatment benefits. Forsch Komplementmed. 2006 Jun;13(3):156-66.

36 Esch BM, Marian F, Busato A, Heusser P. Patient satisfaction with primary care: an observational study comparing anthroposophic and conventional care. Health Qual Life Outcomes. 2008 Sep;6(1):74.

37 Glöckler M. Meditation in der anthroposophischen Medizin: ein Praxisbuch für Ärzte, Therapeuten, Pflegende und Patienten. Salumed Verlag; 2016.

38 Steiner R, Maryon E. Briefwechsel 1912-1924, ed. R.S. Nachlassverwaltung. Dornach: Rudolf Steiner Verlag; 1990 